\section{POST-WAR UNIVERSITY EDUCATION}

\author{
By ProF. FRANK HORTON, F.R.S.
}

$\mathrm{T}$ HE report of the British Association Committee on Post-War University Education, published on August 1, had its origin in the conference on Science and World Order held under the auspices of the Association in September 1941. The Committee was constituted under the chairmanship of Dr. Maxwell Garnett with the following terms of reference :

1. To consider the general policy and methods of university edfication with a view to promoting international collaboration and the free interchange of ideas, and relating university education to the needs and service of the community.

2. To consider the replanning of teaching departments and curricula in accordance with modern conceptions of the interrelation of cula in accordance with modern conceptions of the interrelation of different branch

3. To survey the position regarding teaching material, apparatus books and staff in universities which have been damaged, disorganized or closed as a result of war, and to make recommendations for their rehabilitation.

The Committee published interim reports in 1942 and 1943, in which it set forth its views together with recommendations on various aspects of items 1 and 2 of its terms of reference, in so far as these deal with university education in the United Kingdom, particular points with which these interim reports have dealt being university entrance scholarships, university finance in Great Britain, universities and the public service and universities and adult education. The subject-matter of all these reports together with the findings of the Committee on other matters within its terms of reference are incorporated in the final report which is now published*. This has a preface by Sir Richard Gregory, president of the Association, and is divided into three sections corresponding to the items of the Committee's terms of reference, but deals in the main with those developments of general policy and methods which the Committee considers desirable in both school and university education in Great Britain.

How can we sum up what should be regarded as the outstanding educational needs of the community at the university-level, the satisfaction of which should be aimed at in university policy ? The answer given in the present report is : (1) to get into our universities a larger proportion of those who are going to be the leaders of their generation; (2) having achieved this end, to educate them in such a way as to enable them to cultivate a wider and more integrated outlook on life as a whole; (3) for universities to take a far bigger part than they have done in the past in the education of those who enter the public service, not only before entry, but also after some experience of the service has been gained, and in providing an opportunity of university education for officials of lower rank than have normally enjoyed this privilege ; (4) for the university schools of education to play an essential part in the education of all qualified teachers; (5) an expansion in the provision for vocational and non-vocational adult education.

The consideration of how to achieve the first two of these aims has led the British Association Committee to much serious criticism of present scholarship

* British Association for the Advancement of Science. Report of Committee on Post-War University Education. Pp. 52. (London: British Association, 1944.) 28. $6 d$. examination systems and of both school and university education. The Committee shares the prevalent view that a much more extensive provision of State and local aid to finance a much greater number of students through a university career is essential in our future educational policy. The Committee appears to envisage the increase of the number of these awards to such an extent that, after meeting the needs of all the candidates of outstanding intellectual promise, there would still be a number of awards available for candidates of less ability whose claims to consideration would be based mainly on their possession of social and civic qualities. It would seem that some adequate system would have to be devised for assessing the other factors which contribute to what the Committee terms "universityworthiness". The best the Committee can suggest in this respect is, after making awards to the candidates of high intellectual promise, "to pick the others empirically on a general impression of their scholarship-worthiness and without attempting an order of merit". Here we seem to be up against an identification of university-worthiness with scholarshipworthiness, and a disregard of the fact that, even if the number of awards is greatly increased, it is unlikely that this number will be as large as the number of candidates, so that an order of merit must be decided.

These awards are all spoken of as "scholarships" by the Committee, but we feel very strongly that the term "scholarship" should be limited to an award which is given for high intellectual ability and should not be applied to an emolument awarded mainly for social and civic qualities. The designation "State bursary" which has been used during the War to describe the emoluments awarded by the Board of Education, sometimes to students of little outstanding ability, might perhaps be continued.

It is suggested in the report that to prevent boys and girls of high intellectual ability from having to do a round of scholarship examinations in the hope of obtaining sulficient funds to finance their university careers, winners of open scholarships or exhibitions at Oxford or Cambridge (or successful candidates for admission to the women's colleges at those Universities) should be treated as if they had won national scholarships. So far as open scholarships are concerned it is generally agreed that this would be a good plan, provided the number of such awards is maintained at about its present level and the monetary value of the scholarships is not diminished; but it is clear that such a scheme, if adopted, must apply also to open scholarships awarded at other universities and not be limited to Oxford and Cam. bridge. In regard to the suggestion that all successful candidates for admission to the women's colleges at Oxford and Cambridge should also be treated in this way, one feels that the Committee cannot have realized the consequences of such action. The annual admission to the women's colleges at Cambridge is about 150 and at Oxford about 250, and thus the scheme might involve a yearly total of approximately 400 national awards being ear-marked for women at Oxford and Cambridge out of a grand total of about 1,600 annual awards contemplated for men and women together in all the Universities of England and Wales.

The outstanding theme which underlies all the Committee's criticisms of present higher school certificate examinations, university scholarship examinations and university curricula is over- 
specialization, which the Committee, in common with other bodies which have published opinions on the subject, sees as a menace permeating the whole system of education and resulting in failure to cultivate a wide outlook on life as a whole. The universities are blamed for forcing this overspecialization on the schools by their system of selecting entrance scholars and also by supplying the schools with too high a proportion of specialist teachers. In its effect on boys who are not of exceptional intellectual quality, the scholarship system, especially that part which operates through the higher school certificate examinations, is described as giving rise to a product which, at the end of a university course, is scarcely adequate to the daily experiences and social contacts of a routine job in life. This condemnation of the whole range of the educational system is very sweeping, and we cannot but feel that the members of the British Association Committee must have been singularly unfortunate in their contacts with the products of that system who owe their university careers to their performances in higher school certificate examinations. The universities are taxed also with having failed to develop character and leadership, and with handicapping the growth of these qualities in that fraction from the poorer homes which is admitted to the universities through scholarships, by giving them a "one-sided education of a pernicious kind". So far as we can gather from the report, the perniciousness of the education lies in its specialized character and the lack of what the Committee describes as an integrating principle. 'Pernicious' is a strong word, and we do not see that any case is made out in the report which justifies its use.

The remedy suggested by the Committee begins with a new sixth-form curriculum in schools. The authors of the report would like to see a sixth form programme comprising "four general courses covering, respectively, the humanities, the social sciences, the physical sciences, and the biological sciences, affording a connected and complete, if not very profound, view of the whole of civilisation and life". It is suggested that English expression, a modern language, and sometimes mathematics might also be included, and it is envisaged that half the time spent in class would be devoted to these or a similar range of subjects, and the remaining half to the study of one special subject which would also occupy as much of the pupil's private study as he chose to devote to it. In recommending the allocation of so much of the time spent in class to non-specialist studies, the report goes beyond the suggestions in the report of any other body we have seen, and it is doubtful whether a pupil would gain any real advantage from the general courses unless he were encouraged to spend a proportionate amount of his private time on the subjects they comprise.

Alongside this modification of the sixth-form curriculum, the Committee recommends an increased encouragement of extra-curricular activities, and emphasizes that the effectiveness of the proposed changes would depend upon there being a corresponding modification of all scholarship examinations. It expresses itself as being strongly in favour of following this up by the introduction in universities of a type of general degree course, including both natural science and the humanities, which it hopes many students would take in preference to the more specialist courses. The report gives in some detail an account of what is envisaged as comprising such a course in "Philosophy, Natural and Social". One wonders whether those primarily interested in the study of the humanities would be satisfied with the share allotted to their subjects in the programme outlined. As a course for those chiefly interested in science, there is much to be said in favour of a syllabus of this kind, though there seems to be an over-estimation of what a student is capable of doing properly in a given time in the insistence that candidates for honours, in addition to being examined in the subjects of the course, should have also to translate and comment upon passages from French and German authors, including set books. If the study of the sciences outlined, their history and social significance, is to be serious and not the acquirement of a mere smattering of information, there would surely be little time available for any study of set books in foreign languages which would have real educational value.

For those undergraduates who choose to follow specialist courses in natural science, the Committee advocates the introduction of some study of sociology and citizenship by means of "special interest courses", general courses, and discussion groups, all conducted by persons understanding, and in sympathy with, the background interests of the students. It is not clear whether it is the intention that these studies should play any part in the examination for the degree.

In the conviction that it is the duty of universities to ensure that every undergraduate acquires some appreciation of the world as known by science, the Committee has set out what it considers should be aimed at in a course which is described as "Science for All". The list of subjects which is included in this course is very comprehensive and might perhaps be difficult to deal with in practice, but a strong case is made out for providing some such course.

Under the headings "Education for the Public Service", "Universities and the Education of Teachers" and "Universities and Adult Education" the report covers ground which has been explored by other committees which have recently published reports. The discussion on "World-wide University Collaboration" and the section on "Rehabilitation" gain special interest and importance from the assistance of distinguished academic members of the Allied Nations in their compilation.

In the section of the report which deals with university finance in Great Britain, we are glad to see the British Association putting forward suggestions which the universities themselves have been advocating for a long time, namely, an all-round improvement in the salaries of university teachers, the provision of residential accommodation for students of the newer universities on a much more extensive scale, an increase in the number of teaching officers and technicians on university staffs, and a much more generous expenditure than hitherto on facilities for research work.

On the question of salaries of members of university staffs the report emphasizes the present inadequacy of these in comparison with those ruling in other professions, and states that in the lower ranges they are, in some universities, insulficient to afford a reasonable standard of life under prevailing social conditions. The opinion is expressed that all wholetime professors in all English universities should be in receipt of "at least $£ 1,500$ a year at 1938 prices", and that certain subjects such as engineering and medicine should command salaries up to $£ 2,500$ per 
annum, it being assumed that some form of family allowance scheme will be in operation and applicable to all university personnel. The report, however, makes no suggestion that the salary attached to the headship of a department should, in general, depend upon the size of the department or on the amount of administrative work attached to the headship, nor does it point out that a higher salary scale for all grades of staff should prevail in London, where living expenses are greater than in the provinces-a fact usually recognized in the salaries of other professional persons.

According to the University Grants Committee's "Returns from Universities and University Colleges" for the years immediately preceding the present War, the expenditure on staff salaries formed about one half the total expenditure of universities, so that a general increase in salaries on the scale envisaged will require a large total increase in university incomes. The present total expenditure on staff salaries is

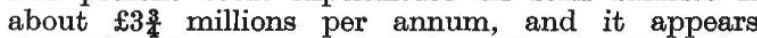
that the increase needed immediately to bring salaries up to the desired level is not less than $£ 1 \frac{1}{2}$ millions per annum, a sum which is about two thirds of the present annual parliamentary grant to universities and university colleges in Great Britain. The Association's report points out that, for the future, universities will inevitably have to look more and more to local and national grants for the needed increases in their resources, and it urges that the Treasury grant should at once be doubled after the War. The rough estimate made above shows that a doubled Treasury grant would need to be supplemented by considerably increased grants from local authorities if university education is to be made available to a greatly increased number of students, for this would involve an enlargement of existing staffs and increased maintenance charges for libraries, laboratories, and social amenities. In addition to increased recurrent grants for maintenance, most universities are urgently in need of large capital grants for the purchase of building sites and for the erection of additional accommodation for students' residences as well as for laboratories, lecture rooms and other buildings.

A novel suggestion in the financial part of the report is that money received by a university for services rendered should not be included in its annual income and expenditure account, but should be paid into a capital account, so that the finances of the institution should not be embarrassed when the services cease to be rendered and the income from this source comes to an end. The earnings mentioned in the report are those of certain medical and scientific departments, but the proposal might perhaps be extended to cover the net profits (if any) from external and school examinations.

Universities are rightly zealous in safeguarding their autonomy, and, in some quarters, fears have been expressed that increased Treasury grants might involve some form of Government control. The British Association Committee states that "the question of control by the Government is certain to be raised", but is of the opinion "that the universities will be strong enough to resist any harmful requirements which the Government might be tempted to couple with substantial increases in State grants". While holding strongly that university autonomy must be preserved, we believe that it would be advantageous to university education generally if a definite lead were given in regard to the directions in which expansion of university activities is most desirable. In the last few months all universities have submitted to the University Grants Committee their schemes for post-war development, and it is hoped that, in due course, large sums will be forthcoming to finance these. It is perhaps unlikely that the total cost of all the developments contemplated will be provided from Government sources, and it seems desirable that when a university is allotted a grant it should be informed which, if any, of the items in its programme are considered to be unnecessary in the national interest, and which are the particular developments in respect of which support is given.

The duties in connexion with the work of advising the Treasury in the distribution of the Government grant to universities have been carried out for twenty-five years by the University Grants Committee in' a manner generally recognized as being altogether admirable, and which has won the full confidence and gratitude of the universities themselves. It surely merits much higher commendation than the somewhat grudging praise given in the British Association Report: "We are of the opinion that the University Grants Committee has done very well in the inter-war years".

The report stresses the desirability of the creation of a universities' advisory council, which should include the vice-chancellors of universities and the principals of university colleges, university teachers of various grades and persons of distinction in other walks of life. The council would have the duties of formulating a national policy of university education and research, of advising the universities on all the national and international aspects of British university problems, and of making representations to the official body which advises the Government on the financial needs of the universities. It seems to us that a committee so constituted would be unwieldy in size, difficult to assemble and unlikely to be able to function usefully in the directions suggested. Moreover, it would be redundant in view of the existence of the Committee of Vice-Chancellors and Principals, and of the Universities Bureau of the British Empire, which latter body will doubtless be considering whether any extension of the range of its activities is desirable having regard to the conditions which will prevail after the cessation of hostilities. The University Grants Committee has recently been reconstituted and enlarged. It has always been able to command such additional expert advice as it has needed from any academic or Government source. It is in constant touch with the Committee of ViceChancellors and Principals, which already fulfils some of the functions set forth above. Moreover, individual universities are often in consultation with Government departments on matters of national and international importance, and it is right that this direct consultation should continue.

One wonders whether those who are pressing for the establishment of a universities' advisory council are really aware of the many claims which are made on the time of a vice-chancellor or of other persons who are specially qualified to speak on university matters. It is important to guard against the danger of such an increase in the time occupied by attending meetings that those who regularly fulfil their duties in this respect become automatically less qualified to offer advice, because of their enforced detachment from their primary duties in their universities. 